\title{
Obituary for Tamara Grummt
}

\author{
Thomas Braunbeck ${ }^{1 *}$, Lothar Erdinger ${ }^{2}$, Fritz H. Frimmel ${ }^{3}$, Henner Hollert $^{4}$, Siegfried Knasmüller ${ }^{5}$, \\ David M. DeMarini ${ }^{6}$, Michael J. Plewa ${ }^{7}$, Susan D. Richardson ${ }^{8}$, Rita Triebskorn', Gisela de Aragão Umbuzeiro ${ }^{10}$ \\ and Paul A. White ${ }^{11}$
}

\begin{abstract}
Tamara Grummt passed away on January 26, 2020 in Oelsnitz/Nogtland, Germany. Tamara was one of the scientific pioneers in the field of environmental toxicology, namely genotoxicity and hygiene of drinking and bathing waters. Her passing is not only a great loss to environmental research and to the global environmental toxicology community - we have lost an outstanding personality with the heart in the right place, who has become, for many of us, a wonderful friend.
\end{abstract}

Tamara was born on December 30, 1955 in LutherstadtEisleben (Saxony, Germany) as one of three children in a miner's family in Röblingen am See. After 12 years of education in primary and secondary schools at Schraplau and Querfurt, she received her High School A level in 1974 and started studying biology at the Martin-Luther-University Halle-Wittenberg (MLU), where she was awarded her diploma in biology in 1979. As a research associate at the Institute of Soil Science at MLU with Prof. Georg Müller, Tamara worked on the influence of weather and crop plants on soil carbon dynamics. In 1982, Tamara completed an internship in the Mutagenicity Test Laboratory of the Institute of Genetics and Crop Plant Research at Gatersleben (now Leibniz-Institute in Saxony-Anhalt) and finally received her PhD in biology in 1983. Since April 1, 1983, Tamara worked as a research associate and later as the head of the Environmental Mutagenesis Group at the Research Institute for Hygiene and Microbiology Bad Elster (now Federal Environment Agency [Umweltbundesamt, UBA], Bad Elster, Vogtland). She was responsible for the establishment of a wide collaboration network and the development of the newly established mutagenicity test laboratory with a broad spectrum of methods including the Ames test, chromosome aberration tests in cell cultures and primary lymphocytes, the UDS and micronucleus tests. In 1990, Tamara completed her postgraduate studies to become a specialist in medicine (specializing in human genetics) and worked at the

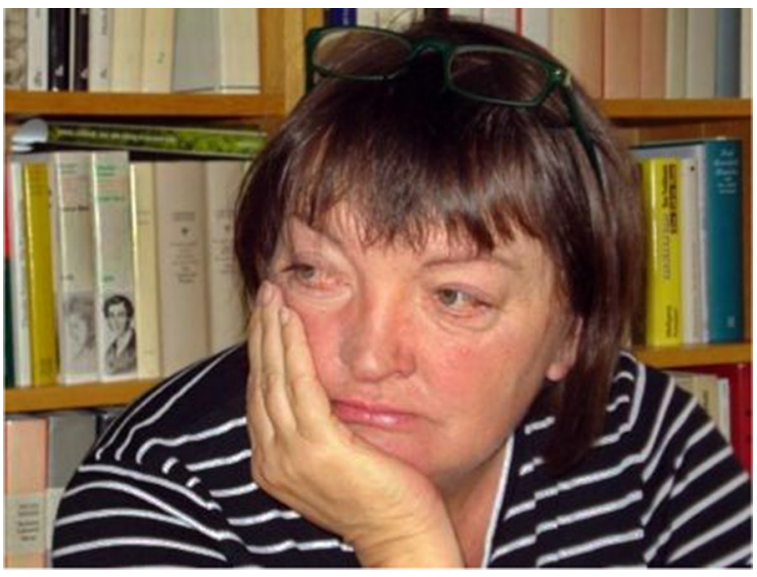

Federal Health Office from 1990 to 1994.Tamara Grummt as she liked to see herself-with a thoughtful look. ${ }^{\odot}$ Federal German Environment Agency (UBA)

*Correspondence: braunbeck@uni-hd.de

${ }^{1}$ Aquatic Ecology and Toxicology, Center for Organismal Studies,

Heidelberg University, Im Neuenheimer Feld 230, 69120 Heidelberg,

Germany

Full list of author information is available at the end of the article

Springer Open

(c) The Author(s) 2020, corrected publication 2020. This article is licensed under a Creative Commons Attribution 4.0 International License which permits use, sharing, adaptation, distribution and reproduction in any medium or format, as long as you give appropriate credit to the original author(s) and the source, provide a link to the Creative Commons licence, and indicate if changes were made. The images or other third party material in this article are included in the article's Creative Commons licence, unless indicated otherwise in a credit line to the material. If material is not included in the article's Creative Commons licence and your intended use is not permitted by statutory regulation or exceeds the permitted use, you will need to obtain permission directly from the copyright holder. To view a copy of this licence, visit http://creativecommons.org/licenses/by/4.0/. 
Since 1994, Tamara has been head of the Department of Toxicology of Drinking and Bathing Pool Water at the Federal Environment Agency/UBA in Bad Elster. In the evaluation of anthropogenic trace substances in drinking water, Dr. Grummt worked in the field of tension between partially or not assessable substances and the toxicological risks for human beings. Under her leadership, a trend-setting guideline for hazard-based risk management for anthropogenic trace substances was developed within the framework of the BMBF collaborative project "Tox-Box" $[1,2]$. The last joint project she initiated was "NeuroBox", a collaborative approach designed to combine both human and environmental approaches in geno- and neurotoxicology [3]. In addition, however, Tamara was a most valuable partner in numerous other projects, the last one focusing on the effect of micro- and nanoplastic particles on human health [4].

Quite unusual for a scientist at a regulatory agency, Tamara's scientific oeuvre continuously grew over many years from 1990 and steeply rose from 2006 and finally culminated in no less than 62 publications listed in the web of science. Even more impressing: To date, the 2007 review "Drowning in disinfection byproducts? Assessing swimming pool water" in Environmental Science \& Technology, which Tamara published together with C. Zwiener (Univ. of Tübingen, Germany), Susan Richardson (formerly U.S. EPA, now Univ. of South Carolina), and David DeMarini (U.S. EPA, Research Triangle Park, North Carolina) and others has received more than 200 citations in web of science [5]. There are several more well-known publications with beyond 100 citations.
Within the agency, Tamara openly and emphatically represented her opinion and stood by her-even to her superiors. Likewise, during her entire scientific carrier, Tamara always put the facts in relation to practice and warned against hysteria: "Drinking water quality has not deteriorated over the years. However, there are new trace substances such as drug residues or even microplastics that need to be evaluated". Thus, Tamara was also a highly respected expert colleague not only in the national German Water Chemical Society since 1999, but across the world. At the national level, she contributed her expertise to the board from 2000 to 2008 and since 2003 as chairperson of the main committee II, "Substances and Water Quality". Since 2016, she has chaired the expert committee "Effect-based assessment of substances in the water cycle" as a competent and tireless contributor to the cause of toxicological assessment in water chemistry. In 2009, Tamara was awarded the Needle of Honor for her outstanding activities in the Water Chemical Society. At the international level, Tamara was a renowned expert who was invited to the U.S., Peru, China, Korea, India, Brazil and many other countries.

However, this obituary is not only meant to be an attempt to chronicle the life of Tamara Grummt or give an extensive list of her many accomplishments, but also to paint an image of the person we learned to know and appreciate through a few thoughts and anecdotes. As a scientist starting her career in the former East Germany, Tamara went through all the nerve-racking changes after

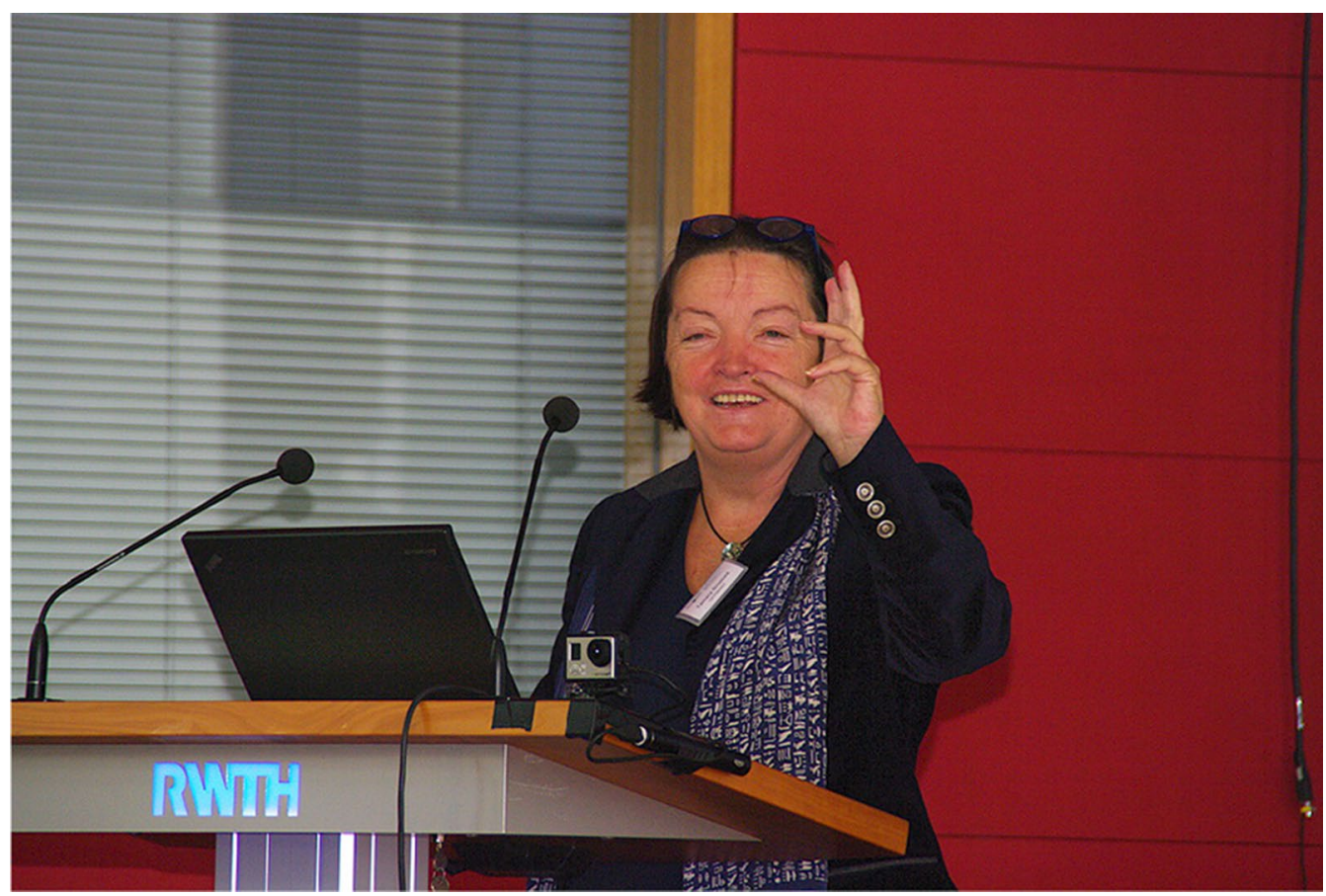

Tamara Grummt advocating the suitability of effect-based methods for the evaluation of drinking water during the opening talk at the BMBF ToxBox Symposium 2015 at RWTH Aachen, Germany: a smile on the face, intoxicating gestures, and a clear thought in the head 
the fall of the Berlin Wall in 1990, however, with a glance of the subtle humor that was so typical of her. As an individual, one of the most striking characters of Tamara was her pronounced sense of humor paired with irony and self-irony. With respect to the fundamental changes in 1990, she was fully aware of realities before and after the fall of the Wall-and expressed her opinion not only thoughtfully, but also clearly and frankly:

"I also recall talking to Tamara about the former East Germany. I was very curious to know what things were like. I asked her, "Do you think the government was keeping track of your movements/activities?" She replied, "I was a government research scientist, of course they were spying on me." I asked, "Now that things are so different, don't you want to look in the Stasi archives to see what they knew and who was passing on information about your activities?" She replied, "Paul, what would I do with that information? To find out that it was the person who mopped the floor or emptied the garbage at the institute? Or worse, that it was a close friend? I don't want to know; much better if I never know. They had no choice, and I forgive them."

(Paul A. White, Health Canada, Ottawa, Canada).

"On another occasion, we were in São Paulo, Bra$z i l$, at an event with carnival-type performances, and Tamara turned to me and said, "Paul do you realize how lucky I am? To be here like this, seeing this show? This would have been impossible when I worked for the GDR. I lived under the thumb of a closed dictatorship. All our movements and all information about the outside world were restricted and controlled. We knew nothing about what the rest of the world was really like. Nothing at all. What we did know was mostly lies..."

(Paul A. White).

Yet, Tamara never denied coming from the former East; however, she also never shut herself off to insight and innovation and was always willing to learn, even if this meant making concessions:

"I first met Tamara in Bad Elster, where she had invited me to speak and work with her group on a project. I arrived a Sunday afternoon, and she appeared at the hotel to meet me and to have a beer before dinner. She informed me that she could not have dinner with me because she had to go back to her house to have dinner with her family, but she wanted to meet and talk with me for a few minutes before seeing me the next day at the laboratory. We had had been talking over our beers for no more than 5 min, when she looked at me and said, "You know, David, the U.S. never put astronauts on the moon; that was all just Hollywood." I was astounded! However, I quickly realized that she had grown up in East Germany, and I understood the situation. Yet, I was still totally shocked. I insisted that indeed the U.S. had first put astronauts on the moon in July of 1969 and that it was not created by Hollywood.

Several years later, I had the distinct pleasure of seeing her again in St. Louis, Missouri, for an analytical chemistry conference to which Susan Richardson had invited us to speak. This was also the first time Tamara had ever been in the U.S. Having grown up near St. Louis, and having been several times to the famous "St. Louis Arch," which sits along the side of the Mississippi River, I told her before she came to St. Louis that the St. Louis Arch was just 2 blocks from our hotel and that she should immediately go to the Arch, go down the escalator to the basement and see the exhibit in the middle of the room in the basement. When I first saw her later that first night, she rushed to me in the lobby of the hotel, gave me a big hug and said "You were right-the U.S. really did put astronauts on the moon in 1969!" I had had her see and touch the moon rocks on exhibit in the middle of the room underneath the St. Louis Arch. We laughed about that event many times over the years back in Germany or at the Gordon Conference in Massachusetts, where I taught her how to open a lobster..."

(David M. DeMarini, U.S. EPA, Research Triangle Park, North Carolina, U.S.).

"I recall that during my last time with Tamara in Germany, we were sitting together and having an energetic conversation regarding in vitro toxicity data. I retorted to one of Tamara's ideas something like "That's crazy!" She replied that we were having a scientific discussion based on data. With a reminiscent look in her eye, she commented that it was crazy to have a scientific discussion based on politics..."

(Michael J. Plewa, University of Illinois, ChampaignUrbana, Illinois, U.S.).

As the head of many working groups and joint projects, Tamara organized numerous meetings and conferences not only in Frankfurt, Berlin and Dessau, but also in Bad Elster, which is quite remote and sometimes difficult to reach:

"I remember arriving to Dessau with David DeMarini to attend a conference Tamara had organized, and we jumped off the train in Germany at "Dessau Sud," thinking that that was the correct stop. Because most cities only had one stop, we assumed that this must be the one for tiny Dessau, so we got off the train, not wanting to miss the quick stop, only to find a deserted, cold war-looking place, 
with run-down buildings and rusted things all over. No problem, though, because we had my printed map to consult. However, when we looked around, no streets on the map matched any streets on my map! Still no problem, we thought we would ask someone for directions, but no one spoke English, only German and Russian), and neither of us spoke either language. But because David always had an international chip in his phone, he promptly called Tamara, and like a flash, she was there with her car to rescue us from this surreal cold war setting..."

(Susan Richardson, formerly U.S. EPA, now Univ. of South Carolina, Columbia, South Carolina, U.S.)

"I once had a "former East Germany" experience with Tamara. I attended the European Environmental Mutagenesis and Genomics Society (EEMGS) meeting in Prague, and I arranged with Tamara to visit Bad Elster after the meeting. She instructed me to take the train to Cheb on the Czech-German border. She said she would send a driver. I went to Cheb, exited the train, and I really did not know where to go. I did not even know who I was supposed to meet, and nobody really spoke English. I exited the station and managed to find a guy with an UBA van. He spoke almost no English at all, but I was pretty sure he was the driver Tamara sent. I figured that even if he was the wrong guy, at least it was an UBA vehicle! I got in the van, and we drove to the Czech-German border (Czech Republic was not yet in the EU). The border guards, who also spoke almost no English, searched us thoroughly. I really had no idea what was going on. I thought maybe it was because the driver was transporting a Canadian guy who he does not even know. I thought "great, the guards won't let me across, and I'll be stuck here in middle of nowhere on the Czech-German border!' It turned out the guards were looking for contraband cigarettes! How could I know that cigarette smuggling was a serious problem? Along the drive we passed along the old border, where there were old Russian guard towers to shoot people trying to sneak across! I felt like I was on another planet. It was all quite surreal. Of course, all worked out. We went to UBA where Tamara was an awesome host. I presented my work, and afterwards we ate sausages and drank beer at UBA! Such a thing would never happen in a Canadian government building - where alcohol is not allowed..."

(Paul A. White, Health Canada, Ottawa, Canada).

The worst that could happen to you was that Tamara insisted on everybody taking at least a sip of the wonderful water from Bad Elster! Nevertheless, everybody was rewarded by a wonderful dinner... In fact, we all enjoyed the many workgroup meeting organized by Tamara and her group-as the German saying goes, "As the Lord, so the tableware", Tamara managed to attract so many people who combined enthusiasm with a well-developed sense of pleasure and satisfaction:

"When I arrived in Hof, a driver from UBA was waiting for me. Tamara warned me that the driver did not speak any English, so I thought I would just stay quiet while he drove me to my hotel. It turned out that although I don't speak German, and he did not speak English, we had a long chat during the entire trip! I learned about the good price of cigarettes and beer at the Czech border during this trip. I don't know how we were able to communicate so well. When I arrived at the hotel, we were already friends, and I started to call him Mr. Wunderbar (which means wonderful) because I was not able to memorize his real name (Wunderlich). At UBA, when I said Mr. Wunderbar, they all laughed. At that moment, I realized how much Tamara's colleagues all loved her and really respected her as a kind and friendly leader..."

(Gisela de Aragão Umbuzeiro, University of Campinas, Limeira, Brazil).

Yet, apart from the devotion to her profession, Tamara managed to create the free space for herself to cultivate her cultural interests: Her appreciation for literature ranged from German to Russian classics. Tamara also loved music and enjoyed going to rock concerts; in her youth to Karat or the Puhdys; in the more mature age of 35, she never missed a German tour of Tina Turner, the Rolling Stones, AC/DC or "her" Bruce Springsteen.

"I remember my first session with Tamara in the RiSKWa-Lenkungskreis and will forever recall how she kept the backbone in discussions with the old silverbacks in water management. When having dinner with her, time went by like in flight, while scientific topics merged with enthusiastically told stories she experienced with her grandkids, an intensive exchange of opinions about the possible scientific base of homeopathy, episodes from holidays and raving about the recent fantastic concert of Bruce Springsteen in Berlin. I will not only miss her sitting close to me as a dear colleague and friend, I already now miss her cheerful and humorous spirit-not only during scientific congresses"

(Rita Triebskorn, University of Tübingen, Germany).

At no time, could Tamara let real or perceived injustice come to an end, no matter what the situation, whether it affected her personally or a co-worker; and if she had to accept it, it was painful, but with the feeling of having stood up against it and opened her mouth. Tamara was not even afraid to bring her concerns to the attention of the President of the Environment Agency, if necessary. 
She was convinced that it often takes little courage to convince with good arguments and to change the way things are viewed. Tamara acknowledged that decisionmakers have their own points of view; yet, in many cases, she did not accept that they might be resistant to advice.

Tamara did not only fascinate young people to become involved in environmental sciences, she was also a rock in the surf when fighting for new and exceptional ideas. Particularly in respect to the use of bioassays in ecotoxicological risk assessment, she challenged the courage of everyone involved to take the step from research into practice.

Tamara Grummt was an amazing person, an outstanding scientist and mentor as well as a brilliant science administrator. Her passing is not only a sad loss for her family and friends, but a big loss to the drinking water research community internationally and especially to the German water regulatory agency. For those of us who knew Tamara personally, her greatest legacy is how she touched our lives with her unique combination of curiosity, creative energy, tolerance, generosity, humor and kindness. We will all miss her very much as a colleague, as an excellent researcher and as a sincere friend; we will keep an honorable memory of her.

May her ideals live on!

Thomas Braunbeck, Lothar Erdinger, Fritz Frimmel, Henner Hollert, SiegfriedKnasmüller, David DeMarini, Michael Plewa, Susan Richardson, RitaTriebskorn, Gisela de Aragão Umbuzeiro \& Paul White
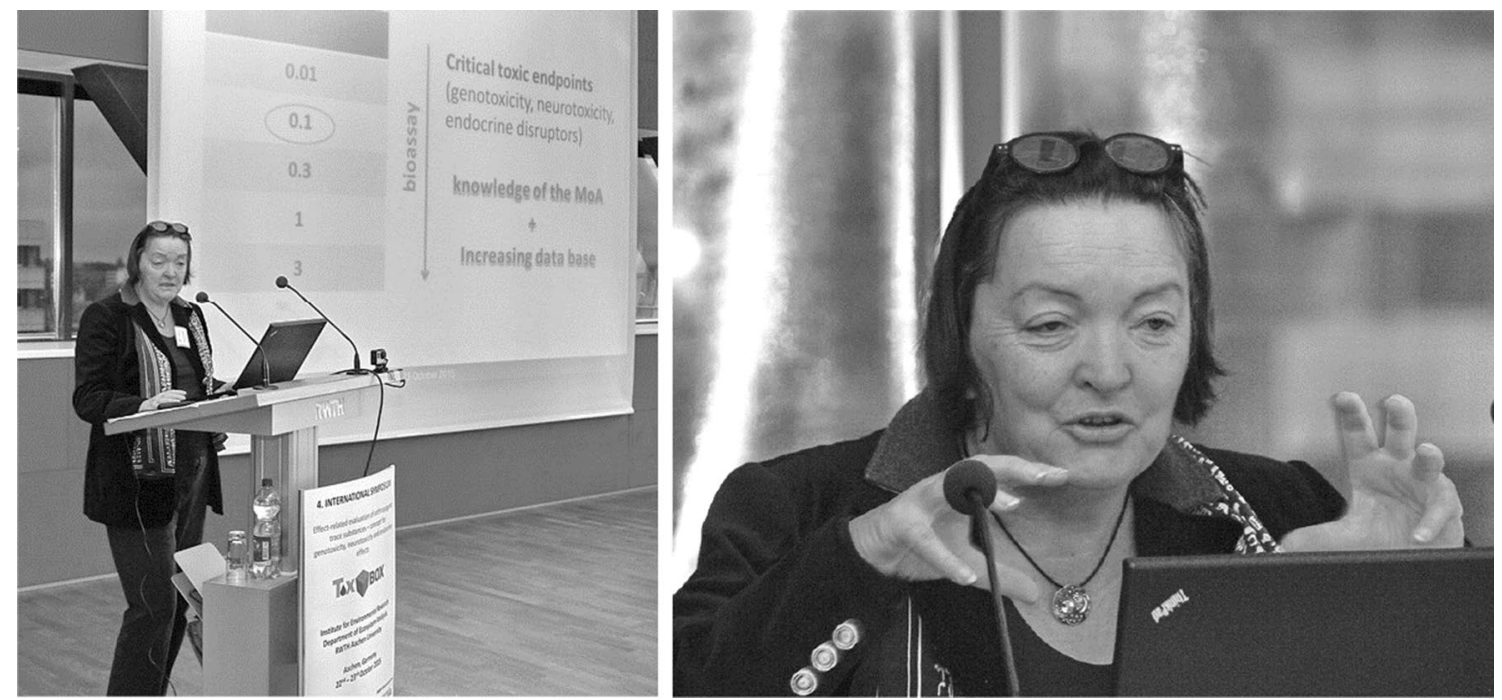

Tamara Grummt as a speaker at scientific conferences: matter-of-fact, forceful and "intoxicating", but with a faint smile at the final conference of the joint BMBF project "ToxBox" (Aachen, Germany; October 22-23, 2015)
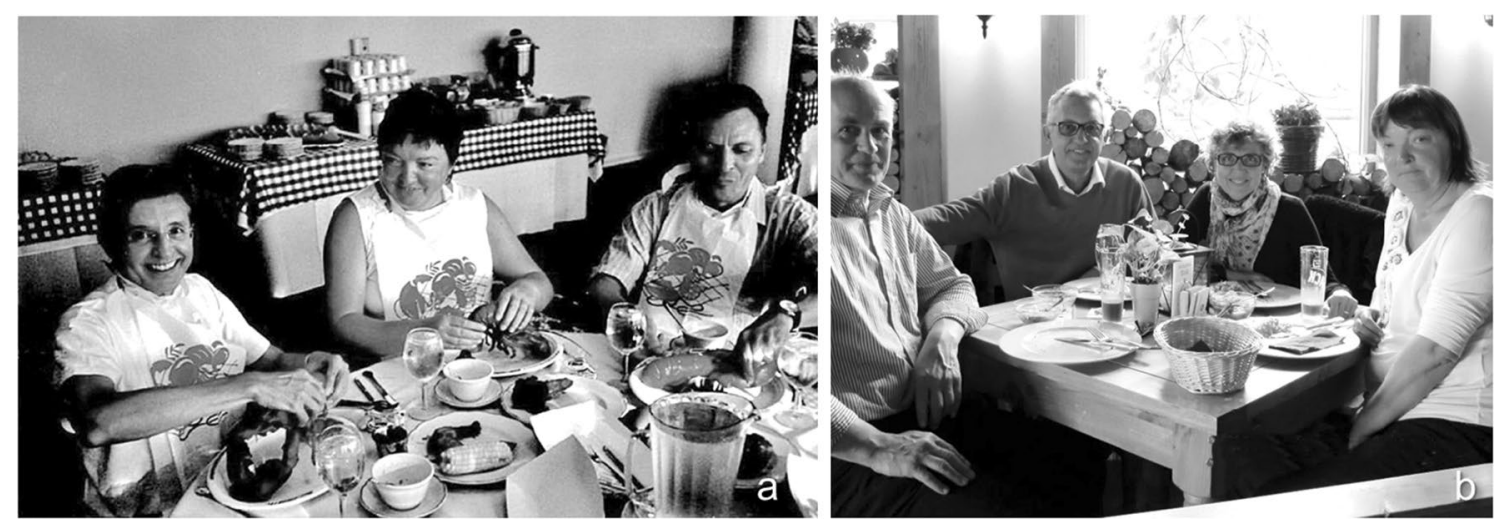

Tamara Grummt as a colleague and friend a at the lobster dinner together with David DeMarini and Christian Zwiener on occasion of the 2006 Water Gordon Conference in Massachusetts (U.S.) and $\mathbf{b}$ at a cozier event for dinner together with her husband Hans-Juergen Grummt (left) and Gisela de Aragão Umbuzeiro and her husband from Brazil (center) at Hof (Germany) on April 17, 2012 


\section{Authors' contributions}

TB conceptualized and drafted the manuscript. LE, FF, HH, SK, DdM, MP, SR, RT, GU \& PW helped to elaborate the text and contributed specific issues. All authors read and approved the final manuscript.

\section{Ethics approval and consent to participate}

Not applicable.

\section{Consent for publication}

Not applicable.

\section{Competing interests}

The authors declare that they have no competing interests.

\section{Author details}

${ }^{1}$ Aquatic Ecology and Toxicology, Center for Organismal Studies, Heidelberg University, Im Neuenheimer Feld 230, 69120 Heidelberg, Germany. ${ }^{2}$ Department of Medical Microbiology and Hygiene, University of Heidelberg, Im Neuenheimer Feld 324, 69120 Heidelberg, Germany. ${ }^{3}$ Engler-BunteInstitut (EBI), Karlsruhe Institute of Technology (KIT), Engler-Bunte-Ring 9a, 76131 Karlsruhe, Germany. ${ }^{4}$ Department of Evolutionary Ecology and Environmental Toxicology, Johann Wolfgang Goethe University Frankfurt am Main, Max-von-Laue-Str. 13, 60438 Frankfurt am Main, Germany. ${ }^{5}$ Institute of Cancer Research, Medical University of Vienna, Borschkegasse 8a, 1090 Vienna, Austria. ${ }^{6}$ Biomolecular and Computational Toxicology Division (B105-03), U.S. Environmental Protection Agency, Research Triangle Park, NC 27711, USA. ${ }^{7}$ College of Agricultural, Consumer \& Environmental Sciences (ACES), University of Illinois, Urbana, 364 National Soybean Res Ctr, 1101 West Peabody Drive, Illinois 61801, USA. ${ }^{8}$ Department of Chemistry and Biochemistry, University of South Carolina, 631 Sumter Street, Columbia, SC 29208, USA. ${ }^{9}$ Animal Physiological Ecology, University of Tübingen, Auf der Morgenstelle 5, 72076 Tübingen, Germany. ${ }^{10}$ School of Technology, State University of Campinas, UNICAMP, Paschoal Marmo Street 1888, Limeira, SP 13484-332, Brazil. ${ }^{11}$ Environmental Health Sciences \& Research Bureau, Environmental and Radiation Health Sciences Directorate, Healthy Environments \& Consumer Safety Branch, Health Canad, Tunney's Pasture Bldg. 8 (P/L 0803A), 50 Colombine Driveway, Ottawa, ON K1A 0K9, Canada.

Published online: 24 April 2020

\section{References}

1. Grummt T, Kuckelkorn J, Bahlmann A et al (2013) Tox-Box: securing drops of life-an enhanced health-related approach for risk assessment of drinking water in Germany. Environ Sci Eur 25:27. https://doi. org/10.1186/2190-4715-25-27

2. Grummt T, Seiler TB, Braunbeck T, Hollert H (2018) Editorial special issue "Effect-related evaluation of anthropogenic trace substances concepts for genotoxicity, neurotoxicity and endocrine effects". Environ Sci Pollu Res 25:3945-3950. https://doi.org/10.1007/s11356-017-1090-z

3. Kuckelkorn J, Frese L, Schuller C, Gundlach M, Haigis A-C, Ogungbemi A, Waldmann P, Weiß S (2020) Projekt NeuroBox - Wie beeinflusst Wasser unser Nervensystem? Vom Wasser 118:1-32

4. Triebskorn R, Braunbeck T, Grummt T, Hanslik L, Huppertsberg S, Jekel M, Knepper TP, Krais S, Müller YK, Pittroff M, Ruhl AS, Schmieg H, Schür C, Strobel C, Wagner M, Zumbülte N, Köhler H-R (2019) Relevance of nanoand microplastics for freshwater ecosystems: a critical review. Trends Anal Chem 110:375-392

5. Zwiener C, Richardson SD, De Marini DM, Grummt T, Glauner T, Frimmel H (2007) Drowning in disinfection byproducts? Assessing swimming pool water. Environ Sci Technol 41:363-372. https://doi.org/10.1021/es062 $367 \mathrm{v}$

\section{Publisher's Note}

Springer Nature remains neutral with regard to jurisdictional claims in published maps and institutional affiliations. 